Available online at: http://ejournal-balitbang.kkp.go.id/index.php/ifrj
e-mail:ifrj.puslitbangkan@ gmail.com
INDONESIANFISHERIES RESEARCHJOURNAL
Volume 23 Nomor 1 June 2017
p-ISSN: 0853-8980
e-ISSN: 2502-6569
Accreditation Number: 704/AU3/P2MI-LIPI/10/2015

\title{
PARASITES AS POTENTIAL STOCK MARKERS FOR TUNA IN INDONESIAN WATERS
}

\author{
Pratiwi Lestari $^{\star 1}$, R.J.G Lester ${ }^{2}$ and Craig Proctor ${ }^{3}$ \\ ${ }^{1}$ Research Institute for Marine Fisheries, JI Muara Baru Ujung, Komplek Pelabuhan Perikanan Samudra Nizam Zahman, Jakarta \\ 14440, Indonesia \\ ${ }^{2}$ School of Biological Sciences, University of Queensland, Brisbane, QLD 4072, Australia \\ ${ }^{3} \mathrm{CSIRO}$ Oceans and Atmosphere Flagship, Castray Esplanade, Hobart, Tasmania 7001, Australia PO Box 1538 \\ Received; June 13-2016 Received in revised from July 04-2017; Accepted August 14-2017
}

\begin{abstract}
Tuna fish are highly migratory species. Clarifying their stock structures and migration patterns is important for tuna fisheries management. The purpose of this research was to examine the parasites of bigeye tuna (Thunnus obesus) and yellowfin tuna (Thunnus albacares) to determine which parasites may be potential stock markers for assessment of tuna migration patterns. Bigeye tuna and yellowfin tuna were collected (measured between 28-48 cm fork length) from 9 sites across Indonesia and from 2 'outlier sites' (The Maldives and Solomon Islands). Organs including gills (filaments and branchial arches), stomach wall, liver, pyloric caeca, and intestines were examined. Seven types of didymozoids were distinguished including 3 Didymosulcus spp., 4 Kollikeria spp. and one acanthocephalan (Bolbosoma sp.). The results suggest these fish parasites are potentially useful markers for assessment of tuna migration pattern, contributing information needed for fisheries management in Indonesia.
\end{abstract}

Keywords: Tuna; parasites; stock markers; Indonesia

\section{INTRODUCTION}

Indonesia's pelagic fisheries resources are important to the nation's economy and as a domestic food resource. Two species of tuna important to Indonesia and to neighbouring countries in the Indian Ocean (IO) and Western and Central Pacific Ocean (WCPO) regions are yellowfin tuna (YFT), Thunnus albacares, and bigeye tuna (BET), T. obesus. Recent stock assessments for these species suggest YFT in both regions and $B E T$ in the $I O$ are marginally exceed the MSY, but that BET in WCPO are exceeding the MSY and the catches may be unsustainable (Davies et al., 2014; Harley et al., 2014; IOTC-SC 16, 2013). However, the assessment neglected the stock structure. The existing assessments based on the assumptions of single panmictic spawning populations of YFT and BET within the $1 O$ and WCPO. However, some recent studies suggested there may be discrete meta populations across the range (Dammannagoda et al., 2008; Nugraha et al.; 2011, Wells et al., 2011; Fraile et al., 2013; Swaraj et al., 2013). The results from tuna tagging programs in the $\mathrm{IO}$ and WCPO also suggest that the movement/mixing rates of YFT and BET may not be as high as previously thought (Hoyle et al., 2013). If populations are discrete, or mixing rates are low within a panmictic population, some populations (or sub-regions) could be susceptible to local overexploitation and improper management decisions.

The use of parasites as biological tags in population studies of marine fish has increased (MacKenzie et al., 2008) because parasite data are relatively inexpensive to collect and the method was globally accepted to identify stock (Lester, 1990; Begg \& Waldman, 1999). If the parasite fauna of fish from two areas was similar, so we construed that the fishes either have grown in a similar environment or have a common history. Where the fauna is different, the histories of the fish are different according to the time scale of the parasites present: recent history for parasites with short residence times in the fish, longterm history for parasites that have remained in the fish for an extended time (Lester, 1990). Methods used to analyse such parasite data are becoming increasingly sophisticated (MacKenzie \& Abaunza, 1998; Perdiguero-Alonso et al., 2008). 
The Didymozoidae is a major family of trematodes which have radiated in pelagic fishes, especially tunas (Scombridae) (Pozdnyakov \& Gibson, 2008). Adult didymozoids found mainly in the tissues of their hosts rather than in the gut lumen. They must therefore be sought specifically through the examination of the tissues where they reside. Another key feature of the family is that the adults retain eggs in the uterus (typically, it is thought, to be dispersed only when the parasite dies), which has the effect of making most didymozoids bright yellow. Many didymozoids form pairs and in some cases there is sexual differentiation into males and females; it is best to keep such pairs together and separate from other individuals so that they can be described as a pair. Many didymozoids are thread-like and may reach lengths in excess of a meter (e.g. Noble, 1975). Such species are challenging to work with. They can only be collected by slow and pain staking dissection of the surrounding tissues. This research aims to investigate parasites as a potential marker to examine the population structure and rates of mixing of YFT and BET across the Indonesian archipelago and connectivity to populations in adjacent ocean regions.

\section{MATERIALS AND METHODS}

BET and YFT were sampled from at 9 locations across Indonesia, namely Padang, Prigi, Palabuhanratu, Bitung, Gorontalo, Kendari, Ambon, Sorong, and Jayapura (Figure 1). They were obtained directly from fishing vessels at time of landing, from local fish markets, and from distribution companies when the catch where the origin could be traced. Gills and viscera were removed, placed into individual plastic bags with a label giving site location, date and time of capture and caudal fork length (FL), and then frozen for later laboratory examination. Additional samples of BET and YFT were collected from two 'outlier' locations, the Maldives and the Solomon Islands.

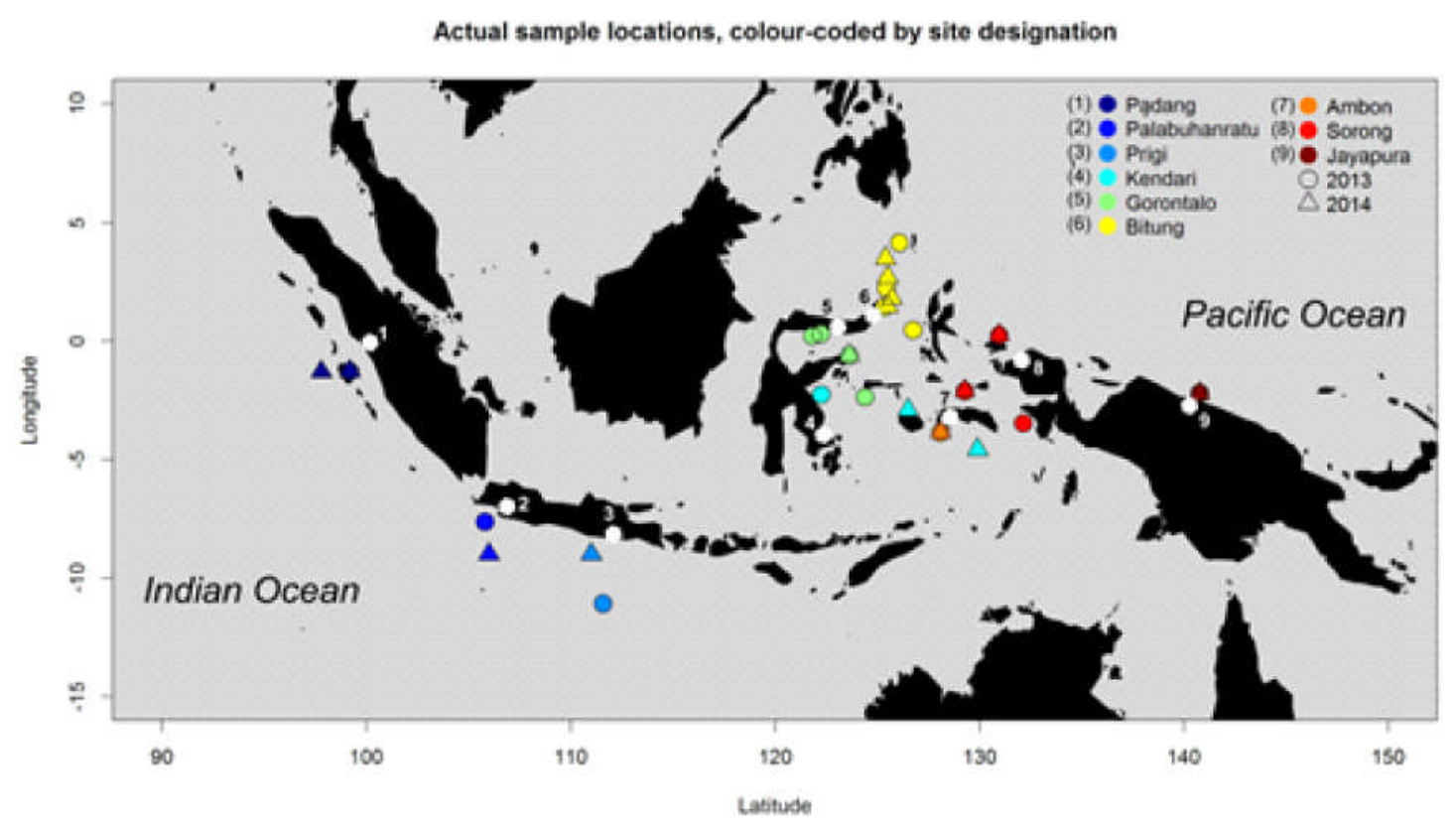

Figure 1. Map showing the Indonesian sampling ports (white symbols) and respective catch locations as understood from the fishermen.

In the laboratory gills and viscera were thawed and dissections carried out according to the methods of Lester et al. (2001). The gill arches were opened and the external and internal gill surfaces examined under a dissecting microscope to find didymozoids. The viscera were separated into stomach, pyloric caeca, intestine and liver. Each organ was placed in an appropriately-sized petri dish and examined progressively under a stereomicroscope. Separation of organs allowed for a clearer examination and also for the accurate recording of the site of infection. Any parasites found were removed and preserved in $70 \%$ alcohol for identification using stereo and compound microscopes and keys and other identification guides for parasites.

\section{RESULTS AND DISCUSSION}

\section{Results}

Ten types of parasites were found in the organs of BET and YFT: 3 types of Didymosulcus, 4 types of Kollikeria, Hirudinella ventricosa, Bolbosoma sp. and Rhadinorhynchus sp. (Tables 1 ). Of the 10 types, 8 appear to be suitable as biological tags. These include the 7 didymozoids (Didymosulcus spp. and Kollikeria spp.), and an acanthocephalan (Bolbosomasp.). 
Table 1. Various parasites identified from organs of BET and YFT

\begin{tabular}{ccc}
\hline \multicolumn{2}{c}{ BIGEYE TUNA AND YELLOWFIN TUNA } & \\
\hline Parasites & Type & Organ \\
Didymosulcus sp. & type 1 & Gill \\
Didymosulcus sp. & type 2 & Gill \\
Didymosulcus sp. & type 3 & Gill \\
Hirudinella ventricosa & & Stomach \\
Kollikeria sp. & type 1 & Stomach wall \\
Bolbosoma sp. & & Stomach wall \\
Rhadinorhynchus sp. & & Stomach wall \\
Kollikeria sp. & type 2 & Liver \\
Kollikeria sp. & type 3 & Pyloric caeca \\
Kollikeria sp. & type 4 & Intestine wall \\
Rhadinorhynchus sp. & & Intestine wall \\
Bolbosoma sp. & & Intestine wall \\
\hline
\end{tabular}

The 3 types of Didymosulcus found in gill arch and filament. Didymosulcus type 1 was comma shaped and found in pairs, embedded in the filaments

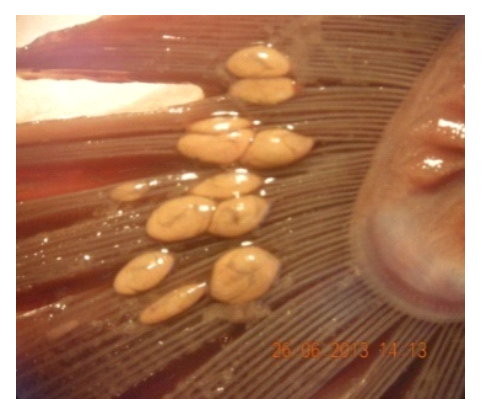

Figure 2. Didymosulcus type 1, a didymozoid in situ in the gills.

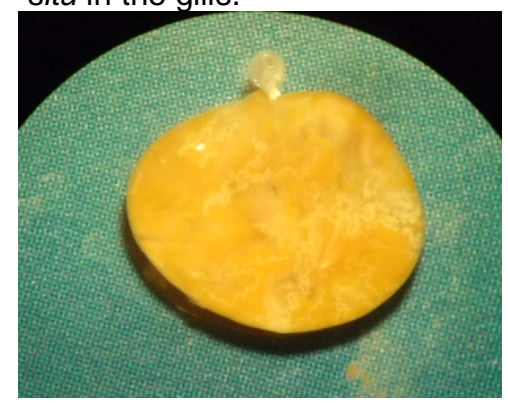

Figure 4. Didymosulcus type 3, a didymozoid from the gills.

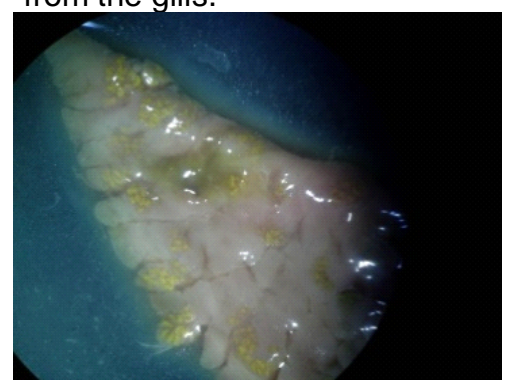

Figure 6. Kollikeria type 2, a didymozoid in situ in the liver. of a gill arch (Fig. 2). Type 2 were elongated (Fig. 3) and Type 3 were more rounded (Fig 4).

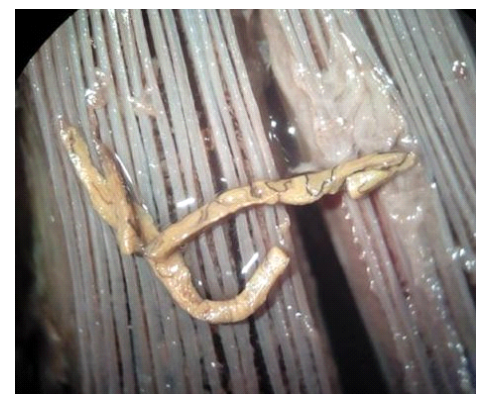

Figure 3. Didymosulcus type 2, a didymozoid in situ in the gills..

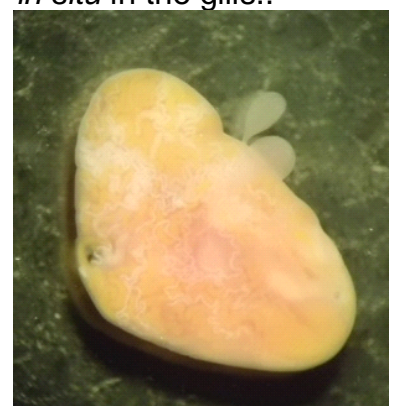

Figure 5. Kollikeria type 1, a didymozoid from the stomach wall.

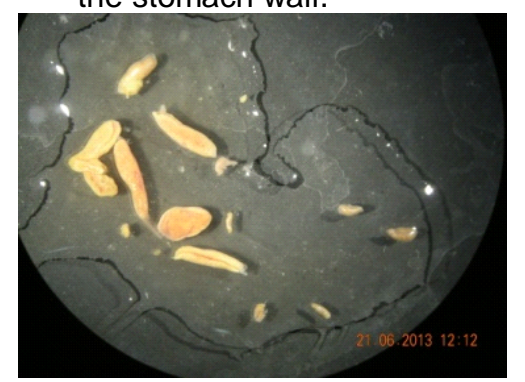

Figure 7. Kollikeria type 3, a didymozoid from the pyloric caeca. 


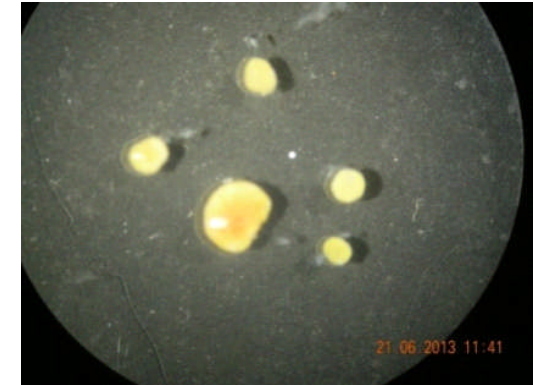

Figure 8. Kollikeria type 4, a didymozoid from the intestine wall.

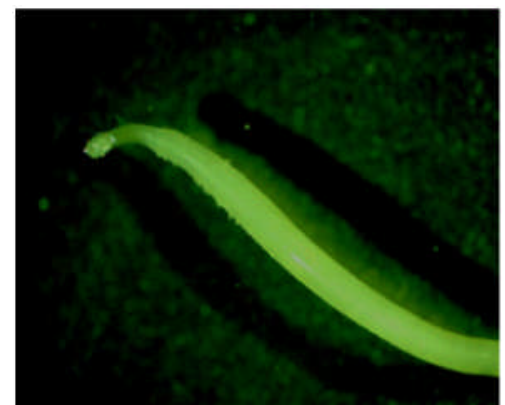

Figure 10. Adult Rhadinorhynchus sp. from the intestinal lumen.

Four types of Kollikeria were found in the viscera. Type 1 from the stomach wall was a globular female within which was a small male (Fig.5). Type 2 were generally found in groups in the liver (Fig. 6). Type 3 were a large species with an elongate shape found in the pyloric caeca (Fig. 7). Type 4 were a small species found in the intestinal wall (Fig.8).

In addition to didymozoids, the giant worm Hirudinella ventricosa (Fig. 9) and 2 genera of Acanthocephala were found in the stomachs. Adult Rhadinorhynchus $s p$. were found in the intestinal lumen (Fig.10). Immature Bolbosoma sp. were generally embedded in the wall of the intestine (Fig. 11). They had a distinct bulge near the proboscis covered with a broad band of small hooks. A second band occurred on the body between the bulge and the proboscis.

\section{Discussion}

Preliminary identifications of the parasites were done using morphological characters (Pozdnyakov \& Gibson, 2008). Future DNA sequencing may show whether the same species of parasites inhabit in both tuna species, or indeed whether the same species of didymozoid lives in different places in the same fish.

The genus Didymosulcus is specific to the family Scombridae and almost specific to tuna. They are considered a potentially dangerous parasite for species of tuna, little tuna and mackerel around the

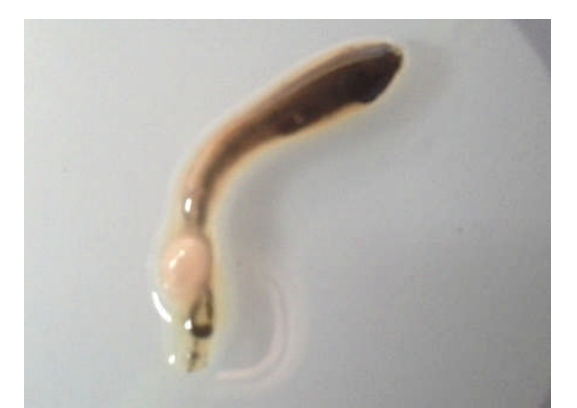

Figure 9. Giant worm, Hirudinella ventricosa from the stomach.

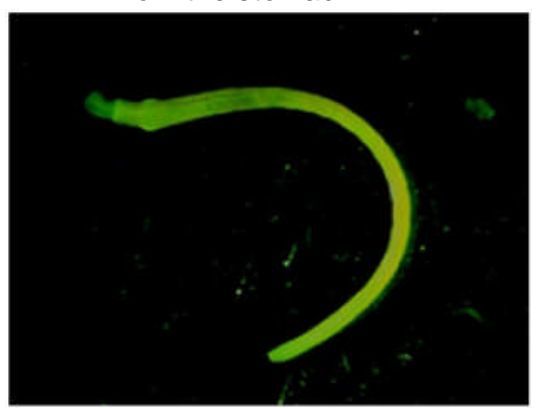

Figure 11. Juvenile Bolbosoma sp. from wall of intestine.

world (Williams \& Williams, 1996), though these and the other parasites are all harmless to humans.

Didymozoids such as Didymosulcus and Kollikeria spp. are thought to release eggs and degenerate when the host fish matures. The probable life cycle involves eggs released from fish being eaten by a pelagic snail. Tiny cercariae develop in the snail and are eventually released into sea water. A cercaria is thought to be eaten by a planktonic copepod, the copepod eaten by small fish and then the small fish is eaten by a tuna.

Seven types of didymozoids and the acanthocephalan Bolbosoma sp. were embedded in host tissue and are considered suitable as biological tags. Parasites have proved useful as biological tags for discrimination of fish stocks and evaluating migrations because during migrations fish move with their parasites (Sinderman, 1961; Gibson, 1972; Wickings \& MacFarlane, 1973; Mackenzie, 1983, 1986; McGladdery \& Burt, 1985; Butorina \& Shedko, 1989; Mackenzie, 1990; Moser \& Hsieh, 1992). As noted by Bailey et al. (1988) and Lester (1990), the geographical variation of the distribution and abundance of parasites is an excellent source of information for examining movements and population structures of marine fishes.

The most suitable parasites are those embedded in the tissues rather than those 'free' in the lumen of the gut. Those in the lumen could have a limited 
residence time in the fish compared with those embedded in tissues. Other stock discrimination studies have focused on juvenile anisakid nematodes or juvenile trypanorhynch cestodes which appear to be more or less permanent within the fish once the fish is infected. These were rare or absent from the fish dissected in this study. The residence time of didymozoids is unknown but those in tuna are thought to release their eggs and degenerate only when the fish matures. If only juvenile tuna are examined as in this study, it could be assumed that once a fish has been infected by a didymozoid the fish will stay infected until examined. Thus the didymozoid parasites here could be considered long-term residents in the fish.

\section{CONCLUSION}

There is seven types of didymozoids ( 3 Didymosulcus spp. and 4 Kollikeria spp.) and an acanthocephalan (Bolbosoma sp.) appear suitable as biological tags since their long residence time in the fish. Information on the distributions of these parasites may help to discriminate between tuna stocks in Indonesian archipelagic waters and thus provide information useful to those managing Indonesia's tuna fisheries.

\section{ACKNOWLEDGEMENTS}

This research was done as part of Indonesia Australia collaboration, ACIAR Project FIS/2009/059, co-funded by ACIAR and CSIRO. We thank all persons and agencies involved in the tuna sampling and Pustika Ratnawati and Arlini Batubara, scientists of Agency of Marine and Fisheries Research and Development, Indonesia, who helped with dissections.

\section{REFERENCES}

Bailey, R. E., Margolis, L. \& Groot, C. (1988). Estimating stock composition of migrating juvenile Fraser River sockeye salmon, Oncorhynchus nerka, using parasites as natural tags. Can. J. Fish. Aquat. Sci. 45, 586-591.

Begg, G.A. \& Waldman, J.R. (1999). An holistic approach to fish stock identification. Fish. Res. 43, 35-44.

Butorina, T. E. \& Shedko, M. B. (1989). The use of parasites as indicators for differentiation of sockeye salmon fry in Lake Azabache (Kamchatka). Parazitologiya 23, 302-308.

Dammannagoda, S.T., Hurwood, D.A., \& Mather, P.B. (2008). Evidence for fine geographical scale heterogeneity in gene frequencies in yellowfin tuna (Thunnus albacores) from the north Indian Ocean around Sri Lanka. Fish. Res. 90, 147-157.

Fraile, I., Murua, I., Zudaire, H., Arrizabalaga, H. \& Rooker, J. (2013). Discrimination of yellowfin tuna from putative nurseries of the Western Indian Ocean. IOTC-2013-WPTT15-36.

Gibson, D. I. (1972). Flounder parasites as biological tags. J. Fish. Biol. 4, 1-9.

Harley, S., Davies, N., Hampton, J. \& McKechnie, S. (2014). Stock assessment of bigeye tuna in the western and central Pacific Ocean, Paper submitted to $10^{\text {th }}$ session of Scientific Committee of Western and Central Pacific Tuna Comission, WCPFC- SC10-2014/SA-WP-01, 115 pp.

Hoyle, S., Kolody, D. \& Nicol, S. (2013). Analyses of tagging data for tropical tunas, with implications for the structure of WCPO bigeye stock assessment. Paper submitted to $9^{\text {th }}$ Session of Scientific Committee of Western and Central Pacific Tuna Comission. WCPFC-SC9-2013/SAIP-06, 67 pp.

IOTC-SC16. (2013). Report of the 16th Session of the IOTC Scientific Committee. Busan, Rep. of Korea, 2-6, December 2013. IOTC-2013-SC16-R (E); $312 p p$.

Lester, R. J.G. (1990). Reappraisal of the use of parasites for fish stock identification. Aust. J. Mar. Freshwater Res. 41, 855-864.

Lester R.J.G., Thompson, C., Moss, H. \& Barker, S.C. (2001). Movement and stock structure of the narrow-barred Spanish mackerel as indicated by parasites. J. Fish Biol. 59, 833-842.

MacKenzie, K., Campbell, N., Mattiucci, S., Ramos, P., Pinto, A.L. \& Abaunza, P. (2008). Parasites as biological tags for stock identification of Atlantic horse mackerel Trachurus trachurus L. Fish. Res. 89, 136-145.

MacKenzie, K. \& Abaunza, P. (1998). Parasites as biological tags for stock discrimination of marine fish: a guide to procedures and methods. Fish. Res. 38, 45-56.

Mackenzie, K. (1990). Cestode parasites as biological tags for mackerel (Scomber scombrus L.), in the Northeast Atlantic. J. Cons. Int. Explor. Mer. 46, 155-166. 
Mackenzie, K. (1983). Parasites as biological tags in fish population studies. Adv. Appl. Biol. 7, 251331.

McGladdery, S. E. \& Burt, M. D. B. (1985). Potential of parasites for use as biological indicatorsof migration, feeding, and spawning behavior of Northwestern Atlantic herring (Clupea harengus). Can. J. Fish. Aquat. Sci. 42, 1957-1968.

Moser, M. \& Hsieh, J. (1992). Biological tags for stock separation in pacific herring Clupea harengus pallasi in California. J. Parasitol. 78, 54-60.

Noble, G.A. (1975). Description of Nematobibothrioides histoidii (Noble, 1974) (Trematoda: Didymozoidae) and comparison with other genera. J. Parasitol. 61, 224-227.

Nugraha, B., Novianto, D. \& Barata, A. (2011). Keragaman genetic ikan tuna matabesar (Thunnu sobesus) di SamuderaHindia. [Genetic diversity of bigeye tuna (Thunnus obesus) in Indian Ocean]. Indonesian Fish. Res. J. 17 (4), 285-292. (In Bahasa with English abstract)

Perdiguero-Alonso, D. (2008). Potential use of helminth parasites in stock identification of flying squid, Ommastrephes bartrami, in North Pacific waters. Can. J. Zool. 69, 1124-1126.
Pozdnyakov, S. E. \& Gibson, D. I. (2008). Family Didymozoidae Monticelli, 1888. In: R. A. Bray, D. I. Gibson, \& A. Jones (Eds.), Keys to the Trematoda. Vol. 3. Wallingford: CABI Publishing and Natural History Museum, pp. 631-734.

Sinderman, C. J. (1961). Parasite tags for marine fish. J. Wildl. Manag. 25, 41-47.

Swaraj, P.K., Kumar, G., Menezes, M.R. \& Meena, R.M. (2013). Mitochondrial DNA analysis reveals three stocks of yellowfin tuna Thunnus albacores (Bonnaterre, 1788) in Indian waters. Conserv. Genet. 14, 205-213.

Wells R.J.D., Rooker, J.R. \& Itano, D.G. (2012). Nursery origin of yellowfin tuna in the Hawaiian Islands. Mar. Ecol. Prog. Ser. 461, 187-196.

Wickings, J. F. \& MacFarlane, I. S. (1973). Some differences in the parasitic fauna of 3 samples of plaice (Pleuronectes platessa L.) from the southern North Sea. J. Fish. Biol. 5, 9-19.

Williams, E. \& Williams, L.B. (1996). Parasites of Offshore Big Game Fishes of Puerto Rico and the western Atlantic. University of Puerto Rico, Mayaguez. 